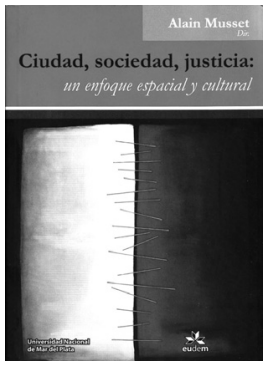

\title{
Alain Musset (dir.). Ciudad, sociedad, justicia: un enfoque espacial y cultural
}

\author{
Mar del Plata: Eudem, Universidad Nacional de Mar del \\ Plata, 2010. 489p.
}

Gabriel San Martín ${ }^{1}$

El libro Ciudad, sociedad, justicia: un enfoque espacial y cultural, es una compilación de trabajos desarrollados en conjunto entre la Universidad de Mar del Plata, la Universidad de París Ouest Nanterre la Defense y la Escuela de Altos Estudios en Ciencias Sociales de París. Obra que tiene como director a Alain Musett, doctor en geografía de nacionalidad francesa y director de la EHESS, el que a lo largo de sus años de investigación ha mostrado un importante interés en el desarroIlo de estudios de las ciudades latinoamericanas y de las relaciones entre sociedad, cultura y medio ambiente.

Editado en Argentina el año 2010 por la Editorial de la Universidad Nacional de Mar del Plata, en 489 páginas, este texto es una recopilación de diversos trabajos que pretenden presentar con una mirada crítica las diversas propuestas que conciernen a los distintos aspectos de las injusticias que se han ido desarrollando en la ciudad del sur y la sociedad en el mundo globalizado, especialmente las vivencias de las poblaciones desfavorecidas.

Dentro de los componentes presentes en este libro, se puede destacar la presencia de un importante apoyo visual que complementa cada uno de los trabajos, sean estos mapas, imágenes o esquemas, graficando de mejor manera lo que se pretende exponer por los autores aquí publicados. Además se puede apreciar un acabado diseño y trabajo en la confección de esta publicación.

\footnotetext{
1 Estudiante de cuarto año de pregrado en Geografía. Instituto de Geografía, Pontificia Universidad católica de Chile (Chile). E-mail: gnsanmar@uc.cl
}

Sin duda alguna que una de las peculiaridades que presenta este libro para llevar a cabo el desarrollo del tema, es que se encuentra dividido en tres partes o ejes que articulan el texto, en ellos se encuentran los artículos que lo componen los que pretenden ejemplificar los aspectos cultural (donde se trata la justicia desde el punto de vista de las sociedades y sus identidades), territorial (donde se ejemplifica la justicia espacial) y, experiencial (mostrando casos concretos en los que se vive la injusticia y cómo la gobernabilidad juega un rol importante en el desarrollo de esta). Con esta ejemplificación se pretende hacer una extrapolación de los componentes de la justicia social que excluyen los elementos espaciales que serían determinados.

Es posible postular que esta es una obra que posee una visión multidisciplinaria y de difusión del tema en cuanto a lo que se pretende proyectar, puesto que si bien maneja conceptos técnicos específicos, puede ser leído por cualquier persona que se interese en la justicia social con un enfoque espacial y cultural. Este carácter de cercanía con el lector está dado principalmente por la existencia de un fuerte análisis que define los conceptos utilizados teóricamente a lo largo del texto, de manera que al momento de enfrentarse a la obra no queden dudas de lo allí tratado y pueda ser comprendido a cabalidad.

Si nos adentramos en el contenido mismo del texto, uno de los argumentos que se da para comenzarlo es que la ciudad es la expresión de la sociedad, por eso estudiarla nos hace contribuir al desarrollo positivo de ella. Donde el territorio no es solo el escenario donde se configuran físicamente las desigual- 
dades económicas sino que juega un papel fundamental en la estructuración y desarrollo de las injusticias sociales (Musset, 2010).

En este sentido podríamos decir que el objetivo principal de este libro es el estudio crítico acerca de la justicia en la sociedad, por ende en la ciudad, y su expresión espacial. El autor trata de mostrarnos cómo los modelos de equidad y justicia social que han sido configurados por filósofos y economistas se han tornado limitados, puesto que no han tomado en cuenta una de las variables más importantes y determinantes que configuran la justicia en la ciudad de manera crucial: la localización y el espacio. La disparidad social espacial no ha sido tema de los actuales estudios de la justicia social. Existe, por parte de algunos autores, una tendencia a obviar estas variables en el modelo de justicia social de manera de simplificar el hecho, por tanto se van creando vacíos y por consecuencia un aumento en las injusticias que se dan en la urbe.

Se ha desarrollado una sociedad donde existe un predominio de las clases poderosas y una fuerte división en segmentos por tanto hay una división de los intereses personales y colectivos de los individuos que la conforman. Es por esto que a lo largo del libro logramos evidenciar cómo las clases económicamente más poderosas e influyentes, es decir, los que tienen el poder de opinión, logran imponerse sobre las poblaciones más desfavorecidas y de esta manera existen organizaciones que han aprovechado esto para implantar sistemas de gobernabilidad en los países con un nivel de desarrollo inferior.

Una de las citas que hace el autor en el texto, y que es una muestra clara de lo que se está pretendiendo presentar en esta obra, es una breve historia que relata el Premio Nobel de economía Amartya Sen, donde tres niños se disputan la posesión de un bien o más concretamente una flauta:

"Solo Ana sabe tocar este instrumento de música, así que por su capacidad personal tendría derecho a recibirlo. Sin embargo,
Bob es tan pobre que dicha flauta sería su único juguete - pues sería injusto que no se lo regalaran. (...) Carla apunta que ella misma diseñó y fabricó este objeto tan codiciado por sus compañeros y que por lo tanto sería un robo quitárselo" (Sen, 2010, citado en Musset, 2010).

En ella los tres niños tienen igual derecho de poseer la flauta, está el que por capacidad es el más indicado para obtener el bien, por otra parte está el que más lo necesita y también está el niño que creó el bien y por ende también le correspondería, sin embargo, hay un cuarto niño que fue olvidado el que no pudo llegar a la disputa puesto que, dada su condición, no tenía los medios para poder desplazarse y ser parte de la competencia por la asignación de la flauta. Lo que demuestra que el concepto de justicia que se ha manejado, no representa a toda la población y por ende, paradójicamente, crea injusticia.

El hilo conductor del libro o unificador de todos los casos que se estudiaron, es Alain Musset, quien luego de hacer la presentación del problema, utiliza todo el material expuesto y tratado a lo largo del texto para poder hacer un análisis en el que concluye que si bien son muchos los avances y estudios que se han hecho con respecto a la injusticia, son también muchas los aspectos que hay que ir revisando para poder lograr un desarrollo del tema aun más preciso y completo.

Una de las conclusiones finales, e importante de destacar, a las que llega el libro es que en cuanto a la justicia social, no pueden ser medidos los límites de injusticia que son capaces de soportar los más vulnerables, a diferencia de la desigualdad que sí puede ser cuantificada. El autor habla de la ciudad utópica que hace referencia a la inexistencia en la actualidad de una real justicia.

A modo de finalización podríamos decir que desde la crítica que se lleva a cabo en el libro, el autor hace un Ilamado a poner atención en el verdadero sentido de este fenómeno, a través de una mejor aproximación y definición de la justicia social. 